\title{
Potential of Directed Cord Blood Donations for the Treatment of Patients with Hematologic Disorders
}

\author{
Thomas Brune $^{a} \quad$ Henk S.P. Garritsen ${ }^{b}$ \\ a University Children's Hospital Magdeburg \\ bInstitute for Clinical Transfusion Medicine, Städtisches Klinikum Braunschweig gGmbH, Germany
}

\author{
Key Words \\ Cord Blood · Hematopoietic stem cells · Leukemia . \\ Stem cell transplantation
}

\section{Summary}

Objective: Directed cord blood donations are donations in which a family that has a child or other family member with a malignant or nonmalignant disease that is potentially treatable with stem cell transplantation, banks cord blood in subsequent pregnancies for future transplantation. With the present study we evaluate the effectiveness of directed cord blood donations. Patients and Methods: Within a 3-year period we analyzed directed cord blood collections in 27 families in which a family member had a malignant (primary hematological) disease. Results: The amount of collected cord blood was $75 \mathrm{ml}$ median $(20-168 \mathrm{ml})$. The amount of CD34+ cells per collection varied from $0.13 \times 10^{6}$ to $30.9 \times 10^{6}$ (median $5.1 \times 10^{6}$ ). Screening for bacterial contamination was negative in all collections. HLA typing of the collected cord blood showed HLA identity to the patient in $8(25 \%)$ of the 32 cord blood collections. In 2 cases $(6.25 \%)$ $1 \mathrm{HLA}$ mismatch was found and in 10 cases $(31.25 \%) 2 \mathrm{HLA}$ mismatches. The other $12(37.5 \%)$ collected cord blood samples displayed at least 3 HLA mismatches. Assuming 2 HLA mismatches as a cut-off for acceptance would mean that $62.5 \%$ of the patients in the investigated group would have an HLA-compatible directed cord blood donation. Conclusions: Our investigation showed that directed cord blood banking is a potential option in families with a family member which has a disorder potentially treatable with stem cell transplantation.

\author{
Schlüsselwörter \\ Nabelschnurblut · Hämatopoetische Stammzellen . \\ Leukämie · Stammzelltransplantation
}

\section{Zusammenfassung}

Hintergrund: Gerichtete Nabelschnurblutspenden sind Spenden, bei denen eine Familie, die ein Kind oder ein anderes Familienmitglied mit einer malignen oder nonmalignen Erkrankung, die potentiell durch eine Stammzelltransplantation behandelbar ist, Nabelschnurblut aus nachfolgenden Schwangerschaften für zukünftige Transplantationen einlagert. Die vorliegende Studie untersucht die Effektivität solcher gerichteter Nabelschnurblutspenden. Patienten und Methoden: Innerhalb einer 3-Jahres-Periode analysierten wir gerichtete Nabelschnurblutspenden in 27 Familien, in den ein Familienmitglied unter einer malignen (primär hämatologischen) Erkrankung litt. Ergebnisse: Die Menge an gesammeltem Nabelschnurblut betrug im Median $75 \mathrm{ml}$ (Bereich 20-168 ml). Die Menge CD34+ Zellen pro Sammlung variierte zwischen $0,13 \times 10^{6}$ und $30,9 \times 10^{6}$ (Median 5,1 $\times 10^{6}$ ). Bei allen Spenden war das Screening für bakterielle Kontaminationen negativ. Die HLA-Typisierung des gesammelten Nabelschnurbluts zeigte, dass 8 (25\%) der 32 Nabelschnurblutspenden HLA-identisch mit dem Patienten waren. In 2 Fällen $(6,25 \%)$ wurde ein 1 HLA-Mismatch, in $12(37.5 \%)$ Fällen 2 HLA-Mismatches gefunden. Bei den anderen 12 Nabelschnurblutspenden zeigten mindestens 3 HLA-Mismatches. Unter der Annahme, dass 2 HLA-Mismatches den Cut-off für die Eignung zur Transplantation darstellen, lässt sich feststellen, dass $62,5 \%$ der Patienten in der untersuchten Gruppe eine HLA-kompatible gerichtete Nabelschnurblutspende bekommen könnten. Schlussfolgerung: Unsere Untersuchung zeigt, dass die Einlagerung von gerichteten Nabelschnurblutspenden eine potentielle Option für Familien darstellt, in denen ein Familienmitglied unter einer Krankheit leidet, die potentiell durch eine Stammzelltransplantation behandelbar ist

\begin{tabular}{ll}
\hline KARGER & @ 2007 S. Karger GmbH, Freiburg \\
$\begin{array}{l}\text { Fax +49 76145207 14 } \\
\begin{array}{l}\text { E-mail Information@Karger.de } \\
\text { www.karger.com }\end{array}\end{array}$ & $\begin{array}{l}\text { Accessible online at: } \\
\text { www.karger.com/tmh }\end{array}$
\end{tabular}




\section{Introduction}

Allogeneic hematopoietic cell transplantation (HCT) is widely accepted as a potential curative procedure for the treatment of acquired or inborn errors of the hematopoietic system. Until now more than 30,000 HCTs were performed worldwide, which corresponds to 4,000 HCTs each year. Emerging new applications of HCT are genetically determined inborn errors of metabolism and autoimmune diseases.

One of the most important prerequisites for a successful allogeneic HCT is the HLA matching of donor and recipient. The level of HLA disparity is decisive for the outcome of the HCT $[1,2]$. A HLA-identical donor within the direct family is found with a probability of $25 \%$ (Mendelian law). The success rate for finding a HLA-identical donor varies from 1:100,000 to $1: 10,000,000$ and can take months ( $~ 80 \%$ success rate within 6 months). Unfortunately, in the case of nonfrequent HLA types (e.g. ethnic minorities) or rapid progressive disease, the search for a suitable HCT donor can take too long or remain unsuccessful.

In recent years alternative methods of obtaining hematopoietic stem cells were evaluated. Besides G-CSF-stimulated peripheral blood stem cell collection, umbilical cord blood donation has evolved into a real option. As more and more cord blood grafts are being used, we gain more insight in the potential and in the restrictions of this stem cell source. There are potential advantages of cord blood stem cell transplants compared to hematopoietic stem cells derived from bone marrow or peripheral blood. The cord blood stem cells have an immature immune response. Data suggest that HLA matching may not need to be as stringent as for PBSC or bone marrow transplantation [3-14]. There has been successful transplantation involving sibling donor cells that do not have perfectly matched HLA compatibility (with up to 2 HLA mismatches). The risk of graft-versus-host disease (GvHD) appears to be lower because of this immature immune response as well [8-16]. An additional benefit is the relative easiness of cord blood collection compared to bone marrow harvesting or peripheral stem cell collection.

Directed cord blood donations are donations in which families that have a family member with a malignant or nonmalignant disease bank cord blood stem cells in subsequent pregnancies for a future HCT. Malignant or nonmalignant diseases potentially treatable by cord blood transplantation include acute and chronic leukemia, lymphoma, aplastic anemia, sickle cell anemia, thalassemia major and a number of other genetic and acquired disorders. To evaluate the effectiveness of directed cord blood donations, we analyzed directed cord blood collections in 27 families from patients having a malignant (primary hematological) disease within a 3-year period in a single institution.
Table 1. Volume of the cryoconserved cord blood and amount of CD $34+$ cells

\begin{tabular}{llll}
\hline & Median & Min & Max \\
\hline Volume, ml & 74.77 & 20 & 168 \\
CD 34+ cells & $5.1 \times 10^{6}$ & $0.13 \times 10^{6}$ & $30.9 \times 10^{6}$ \\
\hline
\end{tabular}

Table 2. HLA compatibility between donor and potential recipient $(\mathrm{n}=32)$

\begin{tabular}{llll}
\hline Match & \multicolumn{2}{l}{ Mismatches } \\
\cline { 2 - 4 } & 1 & 2 & 3 \\
\hline $8(25 \%)$ & $2(6.25 \%)$ & $10(31.25 \%)$ & $12(37.5 \%)$ \\
\hline
\end{tabular}

\section{Patients and Methods}

In a coordinated research effort of the Departments of Obstetrics/Gynecology, Pediatrics and Transfusion Medicine, pregnant mothers of children with a hematological oncological disease were informed about the possibility of donating cord blood (directed cord blood donation) at birth. If they were interested in this possibility, they were informed in detail about the procedure. Further conditions for performing a directed cord blood collection were a negative screening for infectious diseases in the mother. Cord blood collection and processing was performed according to the established standard operating procedures for cord blood.

The cord blood collections were supervised by trained obstetricians. Through a closed collection system the cord blood was collected in a special collection bag, prefilled with anticoagulant (cord blood set: MacoPharma $\mathrm{GmbH}$, Langen, Germany). Only after the person performing the collection was sure that the needle was correctly positioned, the clamp was removed and the cord blood could freely flow into the collection bag. Performing the collection this way prevents suction of air into the collection system and consequently reduces the frequency of bacterial infections. If the blood flow was interrupted, a clamp was attached to the system to save the already collected blood.

The following parameters were evaluated: amount of blood, WBC count, viability, percentage of mononuclear cells, number of precursors and stem cells (CD34, CFU-GM, BFU-E) before cryoconservation. HLA typing was performed according to present standards. In a number of cases an additional volume reduction of the collected cord blood was performed (10 min, $450 \mathrm{rpm}$ ) to discard platelet-rich plasma. Storage was performed by placing the cord blood at $-196 \mathrm{C}^{\circ}$ in liquid nitrogen.

\section{Results}

In total we evaluated 32 directed cord blood collections $(2 \times$ twins, $1 \times$ triplets) for 27 hematological/oncological patients ( 25 children, 2 adults). In 22 patients, the family relation of the donor to the potential recipient was sibling, in 2 patients parent and in 3 cases nephew or niece.

Childbirths could be divided into 24 spontaneous (vaginal) and 8 cesarean sections. The mean birth weight was $3,342 \mathrm{~g}$ 
$(1,650-5,350 \mathrm{~g}) ; 17$ of the infants were female and 15 male. 29 of the infants were mature newborns. The triplets (pregnancy induced by in vitro fertilization) were born in the 35th week of pregnancy. For 1 patient cord blood collections of two different births were reviewed.

Table 1 gives an overview of the collected volume and number of CD34+ cells (before cryoconservation). In case of the triplet, it was only possible with one baby to obtain material for an HLA typing and infectious disease screening. There was not enough material for cryoconservation of the collected cord blood.

The median amount of collected and cryopreserved cord blood was $75 \mathrm{ml}$ (20-168 ml). The median amount of CD 34+ cells per collection $(\mathrm{n}=31)$ was $5.1 \times 10^{6}$ (range $0.13 \times 10^{6}$ to $30.9 \times 10^{6}$ ) (table 1). As can be deducted from table 2, of 32 collections 8 were HLA-identical to the HLA type of the potential recipient $(25 \%)$. In $2(6.25 \%)$ cases, 1 HLA mismatch was present with respect to the potential recipient, and in 10 cases $(31.25 \%) 2$ HLA mismatches could be shown. In the other 12 collections $(37.5 \%)$ at least 3 HLA mismatches were found compared to the HLA type of the potential recipient.

\section{Discussion}

Stem cell transplantation is an important and potentially curative treatment option for a wide variety of malignant and nonmalignant diseases. However, the application of stem cell therapy is more or less dependent on the finding of a genetically compatible donor. This can be a problem in $20 \%$ of the cases. If a suitable donor is identified, there is still the risk of GvHD after transplantation.

Cord blood stem cells can be an alternative source of stem cells for allogeneic transplantation. Since the first successful cord blood transplantation on a 5-year-old boy with Fanconi's anemia in 1988 [11], a lot of things have changed. Nowadays over 5,000 cord blood units have been transplanted worldwide [17, 18]. Wagner et al. [19] published a study of 44 children being transplanted with directed cord blood with a median volume of $5.2 \times 10^{7}$ mononuclear cells per $\mathrm{kg}$ body weight and a failure rate of $11 \%$. One of the presented patients was a 7-year-old boy with Wiskott-Aldrich syndrome. He was successfully transplanted with the directed cord blood of his sibling [20].

The collection of cord blood after birth is relatively simple and without any risk for the mother or the child. In contrast to classical stem cell donors, stored cord blood units are directly available for use. This means no delays through searches for identical donors and no disillusions by donors who do not want to donate stem cells on second thoughts. A further advantage is the reduced frequency of certain infections in cord blood collections, e.g. CMV (only $2 \%$ of the investigated collections was $\mathrm{CMV}+$ in contrast to $40-60 \%$ of CMV+ samples in the general population of stem cell donors). In multiple studies it could be demonstrated univocally that severe rejection reactions $(\mathrm{GvHD})$ are less frequent when using cord blood [5, $9,12,16,19]$. A possible explanation could be the immunological immaturity of the cord blood cells, which could also explain the higher tolerance with respect to HLA mismatches between donor and recipient. Because of the direct availability of the stored cord blood search time can be minimized in comparison to a classical donor. Also for ethnical minorities with rare HLA antigens which are not well represented in the bone marrow registries, stored cord blood could be a welcome additional source for stem cells.

A disadvantage is the limited amount of a cord blood donation, which could be below the threshold of the amount needed for an adult. Also the question as to the minimal amount of nucleated cells per kg body weight, which is needed for an engraftment in an adult, is still open. To circumvent such problems, studies are being performed to transplant double cord blood units. The first results are encouraging [21].

A further critical aspect is the potential correlation between the reduction in GvHD severity and the reduction of graft versus leukemia effect, potentially increasing the frequency of relapses after transplantation of cord blood when compared to other stem cell sources [22]. However, until now no studies support this hypothesis. Moreover, because of the relative short experience with cord blood as a stem cell source, compared with bone marrow stem cells or peripheral blood stem cells, the long-term functioning of the cord blood stem cells is still under investigation.

\section{References}

1 Davies SM, Kollman C, Anasetti C, Antin JH, Gajewski J, Casper JT, Nademanee A, Noreen H, King R, Confer D, Kernan NA: Engraftment and survival after unrelated-donor bone marrow transplantation: a report from the national marrow donor program. Blood 2000;96:4096-4102.

2 Grewal, SS, Barker JN, Davies SM, Wagner JE: Unrelated donor hematopoietic cell tranplantation: marrow or umbilical cord blood? Blood 2003;101: 4233-4244.
Berthou C, Legros-Maida S, Soulie A, Wargnier A, Guillet J, Rabian C, Gluckman E, Sasportes M: Cord blood $\mathrm{T}$ lymphocytes lack constitutive perforin expression in contrast to adult peripheral blood T lymphocytes. Blood 1995;85:1540-1546

4 Brossard Y, Van Nifterik J, De Lachaux V, Huchet J, Chavinie J, Francoual C, Lemanceau G, Benbuman M, Gerota I, Traineau R, et al: Collection of placental blood with a view to hematopoietic reconstitution. Nouv Rev Fr Hematol 1990;32: $427-429$.
5 Broxmeyer HE, Douglas GW, Hangoc G, Cooper S, Bard J, English D, Arny M, Thomas L, Boyse EA: Human umbilical cord blood as a potential source of transplantable hematopoietic stem/progenitor cells. Proc Natl Acad Sci U S A 1989;86: 3828-3832.

6 Broxmeyer HE: Self-renewal and migration of stem cells during embryonic and fetal hematopoiesis: Important, but poorly understood events. Blood Cells 1991;17:282-286. 
7 Broxmeyer HE, Hangoc G, Cooper S, Ribeiro RC, Graves V, Yoder M, Wagner J, Vadhan-Raj S, Benninger L, Rubinstein P: Growth characteristics and expansion of human umbilical cord blood and estimation of its potential for transplantation in adults. Proc Natl Acad Sci U S A 1989;89:4109-4113.

8 Cardoso AA, Li ML, Batard P, Hatzfeld A, Brown EL, Levesque JP, Sookdeo H, Panterne B, Sansilvestri P, Clark SC, et al: Release from quiescence of 34+/38- human umbilical cord blood cells reveals their potentiality to engraft adults. Proc Natl Acad Sci U S A 1993;90:8707-8711.

$\checkmark$ Cairo S, Wagner JE: Placental and/or umbilical cord blood: an alternative source of hematopoietic stem cells for transplantation. Blood 1997;90: 4665-4678.

10 Emerson SG: Ex vivo expansion of hematopoietic precursors, progenitors, and stem cells: the next generation of cellular therapeutics. Blood 1996;87: 3082-3088.

11 Gluckman E, Broxmeyer HA, Auerbach AD, Friedman HS, Douglas GW, Devergie A, Esperou H, Thierry D, Socie G, Lehn P, et al: Hematopoietic reconstitution in a patient with Fanconi's anemia by means of umbilical-cord blood from an HLA-identical sibling. N Engl J Med 1989;321:1174-1178

12 Gluckman E, Rocha V, Boyer-Chammard A, Locatelli F, Arcese W, Pasquini R, Ortega J, Souille G, Ferreira E, Laporte JP, Fernandez M, Chastang C, for the Eurocord Transplant Group and the European Blood and Marrow Transplantation Group: Outcome of cord-blood transplantation from related and unrelated donors. N Engl J Med 1997;337: 373-381.
13 Hao QL, Shah AJ, Thiemann FT, Smogorzewska EM, Crooks GM: A functional comparison of CD34+CD38- cells in cord blood and bone marrow. Blood 1995;86:3745-3753.

14 Harris DT, Schumacher MJ, Locascio J, Besencon FJ, Olson GB, DeLuca D, Shenker L, Bard J, Boyse EA: Phenotypic and functional immaturity of human umbilical cord blood T lymphocytes. Proc Natl Acad Sci U S A 1992;89:10006-10010.

15 Hows JM, Bradley BA, Marsh JC, Luft T, Coutinho L, Testa NG, Dexter TM: Growth of human umbilical-cord blood in longterm haematopoietic cultures. Lancet 1992;340:73-76.

16 Kurtzberg J, Laughlin M, Graham ML, Smith C, Olson JF, Halperin EC, Ciocci G, Carrier C, Stevens CE, Rubinstein P: Placental blood as a source of hematopoietic stem cells for transplantation into unrelated recipients. N Engl J Med 1996; 335:157-166.

17 Rocha V, Labopin M, Sanz G, Arcese W, Schwerdtfeger R, Bosi A, Jacobsen N, Ruutu T, de Lima M, Finke J, Frassoni F, Gluckman E; Acute Leukemia Working Party of European Blood and Marrow Transplant Group; Eurocord-Netcord Registry: Transplants of umbilical-cord blood or bone marrow from unrelated donors in adults with acute leukemia. N Engl J Med 2004;351:2276-2285.

18 Laughlin MJ, Eapen M, Rubinstein P, Wagner JE, Zhang MJ, Champlin RE, Stevens C, Barker JN, Gale RP, Lazarus HM, Marks DI, van Rood JJ, Scaradavou A, Horowitz MM: Outcomes after transplantation of cord blood or bone marrow from unrelated donors in adults with leukemia. N Engl J Med 2004;351:2265-2275.
19 Wagner JE, Kernan NA, Steinbuch M, Broxmeyer HE, Gluckman E: Allogeneic sibling umbilicalcord-blood transplantation in children with malignant and non-malignant disease. Lancet 1995;346 214-219.

20 Cassens U, Garritsen H, Kelsch R, van der Werf N, Frosch M, Witteler R, Ebell W, Sibrowski W: Platelet glycoprotein complex Ia/IIa antibodies cause neonatal alloimmune thrombocytopenia but do not inhibit megakaryopoiesis and platelet recovery after allogeneic cord blood stem cell transplantation. Bone Marrow Transplant 2001;28:803-806.

21 Barker JN, Weisdorf DJ, DeFor TE, Blazar BR, McGlave PB, Miller JS, Verfaillie CM, Wagner JE: Transplantation of 2 partially HLA-matched umbilical cord blood units to enhance engraftment in adults with hematologic malignancy. Blood 2005; 105:1343-1347.

22 Barker JN, Weisdorf DJ, DeFor TE, Blazar BR, Miller JS, Wagner JE: Rapid and complete donor chimerism in adult recipients of unrelated donor umbilical cord blood transplantation after reducedintensity conditioning Blood 2003;102:1915-1919. 